\title{
The Effect of Different pH Levels on Conventional vs. Super-force Chain Elastics
}

\author{
Rogério Lacerda dos Santos ${ }^{\mathrm{a}}$, Matheus Melo Pithon ${ }^{\mathrm{b}}$, Maria Teresa Villela Romanos ${ }^{\mathrm{c}}$
}

\author{
${ }^{a}$ Department of Orthodontics, Federal University of Campina Grande - UFCG, \\ Av. dos Universitários, s/n, Rod. Patos/Teixeira, Km 1, Santa Cecília, CEP 58700-970, Patos, PB, Brazil \\ ${ }^{\mathrm{b}}$ Department of Orthodontics, State University of Sudoeste da Bahia - UESB, \\ Rua José Moreira Sobrinho, s/n, Jequiezinho, CEP 45206-190, Jéquie, BA, Brazil \\ 'Department of Virology, Federal University of Rio de Janeiro - UFRJ, \\ Av. Professor Rodolpho Paulo Rocco, 325, Ilha do Fundão, CEP 21941-617, Rio de Janeiro, RJ, Brazil
}

Received: January 24, 2012; Revised: September 26, 2012

\begin{abstract}
The aim of this in vitro study was to evaluate the influence of $\mathrm{pH}$ levels on force decay and cytotoxicity of elastic chains submersed in artificial saliva. The samples were divided into two groups: Group SF (Polyurethane elastic, super force) and Group C (Polyurethane elastic, conventional), which were stretched to $100 \%$ of their initial length. They were kept in artificial saliva solutions at $\mathrm{pH}$ levels of 5.0, 6.0 and 7.5 for time intervals of 10 seconds, 1,14 and 28 days. Cytotoxicity assay was performed in cells (L929-fibroblast), subjected to "dye-uptake" test. ANOVA, Sidak method and Tukey's test were used. The $\mathrm{pH}$ did not interfere directly in force decay results of tested elastics. Cytotoxicity test showed that Group SF presented similar cell viability when compared with Group C. There was gradual reduction in cell viability from beginning to $28^{\text {th }}$ day. The $\mathrm{pH}$ had no significant influence on force decay and cytotoxicity. Time had more influence and contributed to variability in results.
\end{abstract}

Keywords: elastics, $p H$, force decay, cytotoxicity

\section{Introduction}

Several properties of elastics have been evaluated ${ }^{1-3}$, some involving saliva ${ }^{4}$ or simulated saliva solutions $s^{4-5}$. However, there is a lack of studies on the effects of salivary $\mathrm{pH}$ levels on viscoelastic force relaxation of chain elastics, considering the great individual $\mathrm{pH}$ variability noted within the oral cavity, which can fluctuate with $\operatorname{diet}^{6}$.

Elastic chains are widely used in combination with fixed orthodontic appliances to close or prevent the opening of spaces? ${ }^{7}$. They may also be helpful when used in extrabuccal appliances, as they are easy to handle, have elastic memory and are comfortable for the patient. On the other hand, among their disadvantages are the inconsistency of force levels over time and discoloration. Synthetic elastic chains are made from polyurethane, a linear polymer produced by a chemical reaction between diisocyanate and a polyol ${ }^{8}$. At present the focus has been on elastics that undergo the lowest force decay over the course of mean a period of 4 weeks of clinical use ${ }^{7}$, because the low elasticity may not provide significant tooth movement.

Mechanical behavior studies ${ }^{9-11}$ have observed different parameters, including force decay over time ${ }^{9}$, force decay at different levels of activation ${ }^{10}$ prestretching of the elastic chains $^{11}$, and environmental factors ${ }^{9,11}$. Force decay is higher in the first 24 hours with loss of up $70 \%$ of the initial value, due to relaxation. After this time interval, a more stable phase has been reported with only minor changes of up $20 \%$ in four weeks ${ }^{8-10,12,13}$.

*e-mail: lacerdaorto@hotmail.com
Relaxation, however, is the result of degradation ${ }^{6}$, because force is being measured, and force decay is the term used herein to describe this viscoelastic behavior. On the other hand, studies ${ }^{6,14}$ involving the effects of $\mathrm{Ph}$ levels have not considered whether the force decay-pH ratio would have an influence on the biologic properties of this material. The purpose of the present study was to evaluate the influence of $\mathrm{pH}$ levels on force decay and cytotoxicity of elastic chains submersed in artificial saliva.

\section{Material and Methods}

\subsection{Mechanical degradation and $\mathrm{pH}$ tests}

Two groups of chain elastics of polyurethane with closed filaments (.113-.116 in., distance - center to center): Group SF (Clear, SUPER Elasto-Force, 774-216-00) (Dentaurum, Pforzheim, Germany) and Group C (Clear, Memory, 854-255) (American Orthodontics, Sheboygan, Wisconsin, USA) were evaluated in this study, with a total of 120 sets of elastomeric chain segments for each type of elastic, which were analyzed with regard to the following tests: force decay and cytotoxicity. For each test, 3 different $\mathrm{pH}$ levels (5.0, 6.0 and 7.5) were considered, which were evaluated in the time intervals of 10 seconds, 1,14 and 28 days, totaling a combination of 12 Groups $(\mathrm{n}=10)$.

Six jig boards, each with 10 pairs of pins set $15 \mathrm{~mm}$ apart $^{6}$, were used to test 10 sets of segments of each type of chain elastic for each time interval. The chain elastics 
were stretched to $100 \%{ }^{15-17}$ of their initial length for force measurement, and each jig board was designed with the distance between the pins corresponding to the distance for each group (54 mm for Group SF and $53 \mathrm{~mm}$ for Group C). On each side, half of an additional ringlet was left in place ${ }^{7}$.

Artificial saliva solutions set at prescribed $\mathrm{pH}$ levels of $5.0,6.0$, and 7.5 were provided by the pharmacy school of the Federal University of Rio de Janeiro, Rio de Janeiro. The $\mathrm{pH}$ levels were measured and confirmed using a calibrated pH/ion meter (Model 300, Analyser, São Paulo, SP, Brazil) and were adjusted when necessary, with $1 \mathrm{M}$ citric acid or $1 \mathrm{M}$ sodium hydroxide. Solutions were incubated at approximately $37^{\circ} \mathrm{C}$. The tubs of artificial saliva solution were placed on a rocker (Model TS-8, Meditry, Shanghai, China) oscillating between 25 and $50 \mathrm{rpm}$ during the experiment to help maintain a uniform $\mathrm{pH}$.

The use of 10 continuous chains per treatment combination made it possible for the groups to be tested simultaneously at the same $\mathrm{pH}$ level in time intervals of 10 seconds, 1,14 and 28 days. The force was recorded from readouts taken from a horizontally secured and calibrated digital force gauge (Imada DS2-11, accuracy $\pm 0.2 \%$, Imada Inc., Northbrook, IL, USA), once a consistent reading was established, usually 4 to 5 seconds. All chain elastics had recent manufacturing dates and were randomly segmented from their respective bobbins and were appropriately distributed. The tester was blinded as regards the type of chain elastic that was on each dowel pin. Although there was some difference in color tonality and/or size of the links between different brands because of their manufacturing systems, the tester received the samples separated by group, without brand identifications, and had no previous knowledge about the brands.

\subsection{Cytotoxicity test}

After the force decay test, the elastics were submitted to cytotoxicity testing. Previously, the chain elastics were superficially washed with deionized water (Millipore, Bedford, MA, USA) for 5 seconds and sterilized on both sides by ultraviolet light irradiation (Labconco, Kansas, Missouri, USA) for 30 minutes ${ }^{1,18}$.

To verify the cell response to extreme situations, another three groups were included in the study: Group CC (cell control), consisting of cells not exposed to any material; Group C+ (positive control), with Tween 80; and Group C-(negative control), with PBS solution in contact with the cells.

Cell culture containing L-929 line cells (mouse fibroblast) (American Type Culture Collection - ATCC, Rockville, MD) was maintained in Eagles' minimum essential medium (Cultilab, Campinas, São Paulo, Brazil) by adding $0.03 \mathrm{mg} \cdot \mathrm{mL}^{-1}$ of glutamine (Sigma, St. Louis, Missouri, USA), $50 \mu \mathrm{g} \cdot \mathrm{mL}^{-1}$ of garamicine (Schering Plough, Kenilworth, New Jersey, USA), $2.5 \mathrm{mg} \cdot \mathrm{mL}^{-1}$ of fungizone (Bristol-Myers-Squibb, New York, USA), $0.25 \%$ of sodium bicarbonate solution (Merck, Darmstadt, Germany), 10 mM of HEPES (Sigma, St. Louis, Missouri, USA), and $10 \%$ bovine fetal serum (Cultilab, Campinas, São Paulo, Brazil) for the growth medium or no bovine fetal serum for the maintenance medium only. After this, the cell culture medium was incubated at $37^{\circ} \mathrm{C}$ for 48 hours.
The method for cytotoxicity evaluation was the "dye-uptake" test ${ }^{19}$, based on neutral red dye incorporated into live cells. In this experiment it was used only for the following evaluation periods: 10 seconds, 1 , 14 and 28 days, which represent the time intervals during which chain elastics were kept under cell culture conditions before being removed from them.

\subsection{Dye-uptake}

Volumes of $100 \mu \mathrm{L}$ of L-929 line cells were distributed into 96-well microplates. After 48 hours, the growth medium was replaced with $100 \mu \mathrm{L}$ of Eagles' minimum essential medium (MEM) obtained after incubation in the chain elastics and positive and negative control for 10 seconds, 1,14 and 28 days. Positive and negative control groups consisted of culture medium placed in contact with $100 \mu \mathrm{L}$ of Tween 80 and $100 \mu \mathrm{L}$ PBS solution, respectively.

After 24-hours incubation, $100 \mu \mathrm{L}$ of $0.01 \%$ neutral red dye (Sigma, St. Louis, Missouri) was added to the culture medium in the 96-well microplates, which were incubated again for 3 hours at $37^{\circ} \mathrm{C}$ so that the red dye could penetrate the live cells. After this period of time, $100 \mu \mathrm{L}$ of $4 \%$ formaldehyde solution (Vetec, Rio de Janeiro, Brazil) in PBS (130 mM of $\mathrm{NaCl} ; 2 \mathrm{mM}$ of $\mathrm{KCl} ; 6 \mathrm{mM}$ of $\mathrm{Na}_{2} \mathrm{HPO}_{4} 2 \mathrm{H}_{2} \mathrm{O} ; 1 \mathrm{mM}$ of $\mathrm{K}_{2} \mathrm{HPO}_{4} 1 \mathrm{mM}$; pH 7.2) were added in order to promote cell attachment to the plate. After 5 minutes, $100 \mu \mathrm{L}$ of $1 \%$ acetic acid (Vetec, Rio de Janeiro, Brazil) and 50\% methanol (Vetec, Rio de Janeiro, Brazil) were added in order to remove the dye. After 20 minutes, a spectrophotometer (BioTek, Winooski, Vermont, USA) at $492 \mathrm{~nm}$ wavelength $(\lambda=492 \mathrm{~nm})$ was used to read the data.

\section{Statistical Analysis}

The standard deviation of the load measurements was estimated to be $0.11 \mathrm{~N}^{20}$. With a sample size of 10 segments of chain elastics per treatment combination (total sample size of 2 materials $* 3 \mathrm{pH}$ levels $* 4$ time points $* 10$ chains per group $=240$ ), the study was designed to have at least $80 \%$ power to detect a difference of $0.2 \mathrm{~N}(20 \mathrm{~g})$ between any two treatment combinations, assuming two-sided tests at a 5\% significance level for each set of comparisons among treatment combinations. The effects of material, $\mathrm{pH}$, and time on measured loads were assessed using three-way analysis of variance (ANOVA). Pair-wise comparisons between treatment combinations were adjusted for multiple comparisons using the Sidak method. Because of non-normal distribution of the loads, analyses were performed using the ranks of the measurements. The cytotoxicity test data presented normal distribution and were compared by analysis of variance (ANOVA), and Tukey's multiple comparison test was used to identify differences between the groups. The level of significance was set at $\mathrm{P}<.05$.

\section{Results}

\subsection{Mechanical degradation and $\mathrm{pH}$ tests}

Considering the time point for the same $\mathrm{pH}$ in both the groups ( $\mathrm{SF}$ and $\mathrm{C}$ ), there were no significant differences $(\mathrm{P}>.05)$, except at the time of 10 seconds $(\mathrm{p}=.008)$ 
(Table 1). However, when the time points, $\mathrm{pH}$ and groups were considered simultaneously, there were statistically significant differences $(\mathrm{P}<.05)$ (Table 1, Figures 1 and 2). Force decay was directly proportional to the increase in evaluation time. Group SF showed better performance with higher force release at the time of 10 seconds, however, after 24 hours the super-force elastic showed values similar to the conventional, a force decay of $61 \%$ against $29 \%$ of the $\mathrm{C}$ group (Table 1, Figures 1 and 2). In the time intervals of 1,14 and 28 days, the performance of both the chain elastics were similar. The $\mathrm{pH}$ did not interfere directly in the decay results of the tested elastics.

\subsection{Cytotoxicity test}

Viability was established by comparison with the viability of control cells, which was arbitrarily set at $100 \%$. Group SF showed similar viability when compared with Group $\mathrm{C}$ during the entire experiment. There was gradual reduction in cell viability from beginning to $28^{\text {th }}$ day (Figures 3 and 4). Cell viability ranged from $97.5 \%$ $( \pm 2.26 \%)$ to $91 \%( \pm 3.32 \%)$ in Group SF and from $97 \%$ $( \pm 2.43 \%)$ to $90 \%( \pm 3.37 \%)$ in Group $\mathrm{C}$ in comparison with control cells (Table 2, Figures 3 and 4). A significant difference $(\mathrm{P}<.05)$ was found between the groups $\mathrm{SF}$ and $\mathrm{C}$ with the control group of cells (CC), except at the time point of 10 seconds and between the Groups CC and SF at the time point of 24 hours vs. pH 5 and $\mathrm{pH} 6$ and between Groups $\mathrm{CC}$ and $\mathrm{C}$ at the time point of 24 hours vs. pH $6(\mathrm{P}>.05)$ (Table 2, Figures 3 and 4).

\section{Discussion}

Studies ${ }^{1,2,4,5,14}$ have sought to highlight the environmental and mechanical factors that may be related to the force decay of orthodontic elastics. However, there is a lack of studies on the effects of salivary $\mathrm{pH}$ levels on viscoelastic force relaxation of chain elastics.

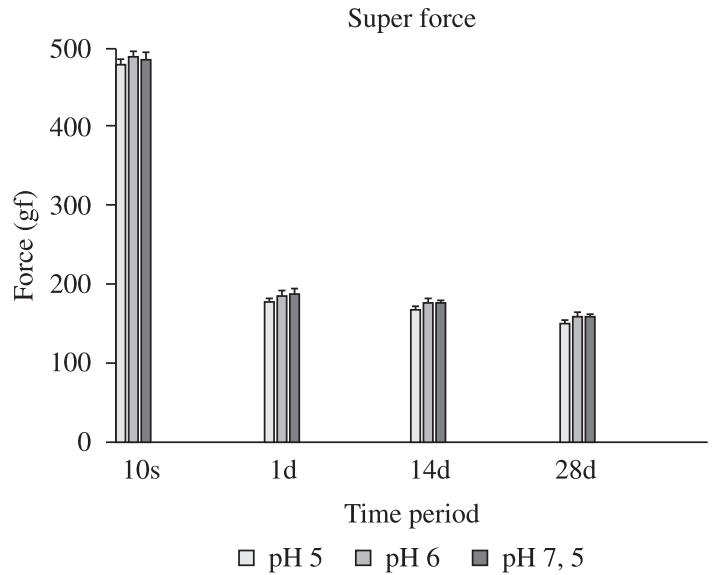

Figure 1. Elastic force decay (mean and standard deviation) of super-force chain elastics (Group SF), for the different $\mathrm{pH}$ levels and times evaluated.

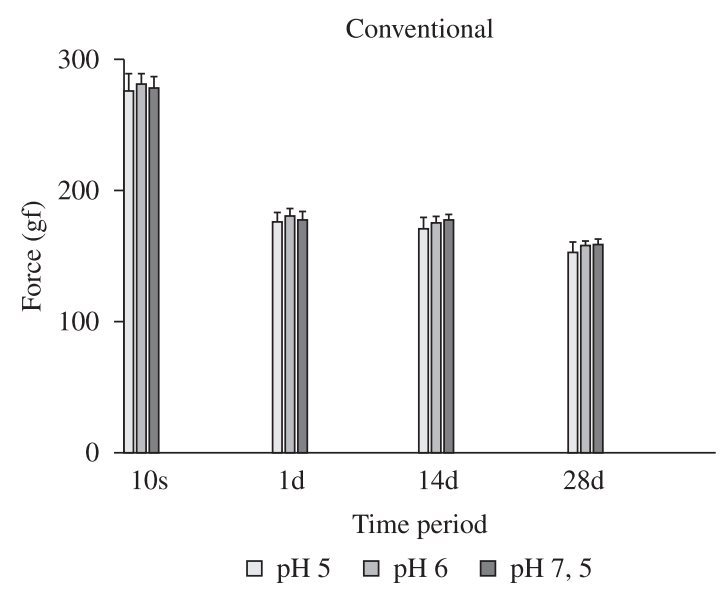

Figure 2. Elastic force decay (mean and standard deviation) of conventional chain elastics (Group C), for the different $\mathrm{pH}$ levels and times evaluated.

Table 1. Mean (gf), standard deviation (in parentheses) and force decay (for time point) of chain elastics.

\begin{tabular}{|c|c|c|c|c|}
\hline \multirow{2}{*}{ Time } & \multirow{2}{*}{ pH } & \multicolumn{2}{|c|}{ Groups } & \multirow{2}{*}{ Statistically } \\
\hline & & SF & C & \\
\hline \multirow{3}{*}{ Initial (A) } & 5 (A1) & $480(8.1)$ & $276(13.2)$ & $S$ \\
\hline & $6(\mathrm{~A} 2)$ & 491.1(8.6) & $280.5(8.6)$ & S \\
\hline & $\mathbf{7 , 5}(\mathrm{A} 3)$ & $488(9.9)$ & $277(9.9)$ & S \\
\hline \multirow{3}{*}{$1 \mathrm{~d}(\mathrm{~B})$} & $5(\mathrm{~B} 1)$ & $178.2(5.0)$ & $175.2(7.8)$ & NS \\
\hline & $6(\mathrm{~B} 2)$ & $186.9(6.1)$ & $179.6(6.1)$ & NS \\
\hline & 7,5 (B3) & $189.2(6.0)$ & $177(6.2)$ & NS \\
\hline \multirow{3}{*}{$14 \mathrm{~d}(\mathrm{C})$} & $5(\mathrm{C} 1)$ & $169(4.2)$ & $170(9.2)$ & NS \\
\hline & $6(\mathrm{C} 2)$ & $178.2(5.0)$ & $174.5(5.2)$ & NS \\
\hline & 7,5 (C3) & $177.1(4.1)$ & $176.3(4.1)$ & NS \\
\hline \multirow{3}{*}{ 28d (D) } & 5 (D1) & $151.3(4.2)$ & $152.1(8.1)$ & NS \\
\hline & $6(\mathrm{D} 2)$ & $159.8(4.1)$ & $157.1(4.0)$ & NS \\
\hline & 7,5 (D3) & $159(4.2)$ & $158.1(4.1)$ & NS \\
\hline Statistically* & & $\begin{array}{c}\mathrm{A} \neq \mathrm{B}-\mathrm{C}-\mathrm{D}, \mathrm{B} 3 \neq \mathrm{C} 1, \mathrm{~B} \neq \mathrm{D} \\
\mathrm{C} 2 \neq \mathrm{D}, \mathrm{C} 3 \neq \mathrm{D} 1\end{array}$ & $\begin{array}{c}\mathrm{A} \neq \mathrm{B}-\mathrm{C}-\mathrm{D}, \\
\mathrm{B} 1 \neq \mathrm{D} 1, \mathrm{~B} 2-\mathrm{B} 3 \neq \mathrm{D}, \\
\mathrm{C} 2 \neq \mathrm{D} 1, \mathrm{C} 3 \neq \mathrm{D} 1-\mathrm{D} 2\end{array}$ & \\
\hline
\end{tabular}

$\mathrm{N}=10$, for each combination of time, $\mathrm{pH}$ and elastic. Significant differences are indicated below each strain table for time intervals (A through $\mathrm{D})$ and the right for groups (SF and C) for the same time and $\mathrm{pH}$. *Statistically: Significant $(\mathrm{S}$ or $\neq$ ) or Nonsignificant (NS). 
When considering the type of study, the in vitro type has major advantages when it comes to the characterization of materials. The oral cavity presents an environment that is very difficult to standardize. Variations such as: microbial flora, enzyme levels, food, force application, all result in poor validity in terms of the evaluation of specific material properties $^{7}$, as has been noted in in vivo studies that have high standard deviation, resulting in insignificant differences

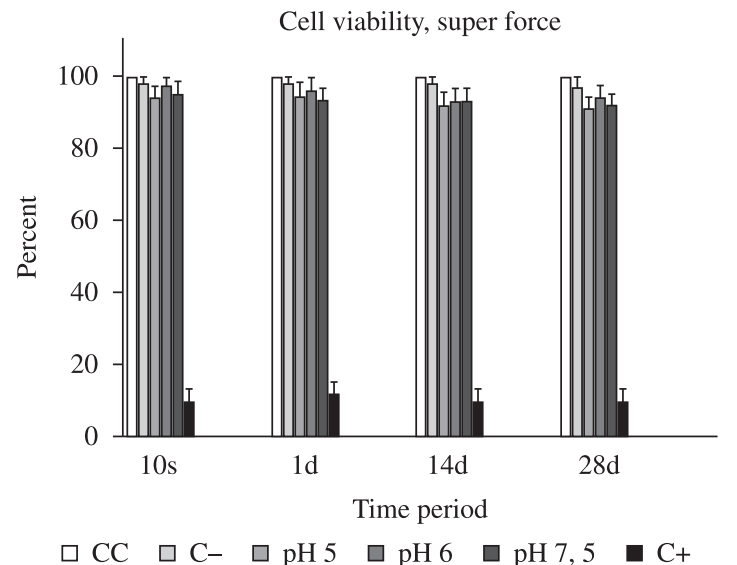

Figure 3. Cell viability (in percent) of super-force chain elastics (Group SF), for the different $\mathrm{pH}$ levels and times evaluated, and control Group: Group CC (cell control), Group C- (PBS solution) and Group C+ (Tween 80).

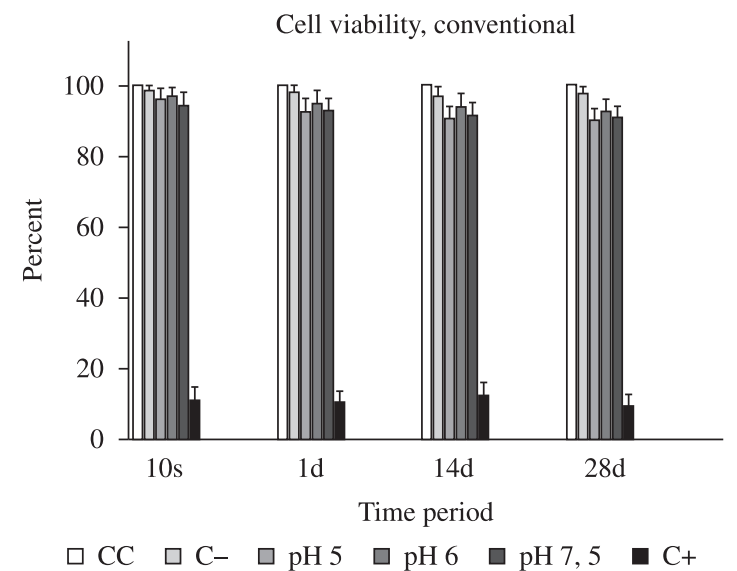

Figure 4. Cell viability (in percent) of conventional chain elastics (Group C), for the different $\mathrm{pH}$ levels and times evaluated, and control Group: Group CC (cell control), Group C- (PBS solution) and Group C+ (Tween 80).

Table 2. Mean (in percentage), standard deviation (in parentheses) of cell viability (for time point) of chain elastics.

\begin{tabular}{|c|c|c|c|c|}
\hline \multirow{2}{*}{ Time } & & \multicolumn{2}{|c|}{ Groups } & \multirow{2}{*}{ Statistically* } \\
\hline & & SF & $\mathrm{C}$ & \\
\hline \multirow[t]{6}{*}{ Initial (A) } & $\mathrm{CC}$ & 100.0 & 100.0 & NS \\
\hline & C- & $98(1.98)$ & $98.5(1.45)$ & NS \\
\hline & pH 5 (A1) & $94(3.3)$ & $96(3.3)$ & NS \\
\hline & $6(\mathrm{~A} 2)$ & $97.5(2.2)$ & $97(2.4)$ & NS \\
\hline & 7,5 (A3) & $95(3.6)$ & $94.5(3.6)$ & NS \\
\hline & $\mathrm{C}+$ & $9.5(3.8)$ & $11(3.8)$ & NS \\
\hline \multirow[t]{6}{*}{ 1d (B) } & $\mathrm{CC}$ & 100.0 & 100.0 & NS \\
\hline & C- & $97.5(2.4)$ & $98(1.9)$ & NS \\
\hline & pH 5 (B1) & $94.5(3.8)$ & $92.4(3.8)$ & NS \\
\hline & 6 (B2) & $96(3.9)$ & $95(3.9)$ & NS \\
\hline & 7,5 (B3) & $93.5(3.3)$ & $93(3.3)$ & NS \\
\hline & $\mathrm{C}+$ & $12(3.2)$ & $10.5(3.2)$ & NS \\
\hline \multirow[t]{6}{*}{ 14d (C) } & $\mathrm{CC}$ & 100.0 & 100.0 & NS \\
\hline & C- & $98(1.95)$ & $97(2.75)$ & NS \\
\hline & pH 5 (C1) & $92(3.6)$ & $90.5(3.6)$ & NS \\
\hline & $6(\mathrm{C} 2)$ & $93(3.8)$ & $93.9(3.8)$ & NS \\
\hline & $\mathbf{7 , 5}(\mathrm{C} 3)$ & $93(3.7)$ & $91.5(3.7)$ & NS \\
\hline & $\mathrm{C}+$ & $10(3.7)$ & $12.5(3.7)$ & NS \\
\hline \multirow[t]{6}{*}{ 28d (D) } & $\mathrm{CC}$ & 100.0 & 100.0 & NS \\
\hline & $\mathrm{C}$ - & $96.9(2.95)$ & $97.5(2.4)$ & NS \\
\hline & pH 5 (D1) & $90.9(3.3)$ & $90(3.3)$ & NS \\
\hline & 6 (D2) & $93.9(3.6)$ & $92.4(3,6)$ & NS \\
\hline & 7,5 (D3) & $92(3.2)$ & $90.9(3.2)$ & NS \\
\hline & $\mathrm{C}+$ & $9.8(3.3)$ & $9.5(3.3)$ & NS \\
\hline Statistically* & & $\mathrm{CC} \neq \mathrm{B} 3-\mathrm{C}-\mathrm{D}, \mathrm{A} 2 \neq \mathrm{D} 1$ & $\begin{array}{c}\mathrm{CC} \neq \mathrm{B} 1-\mathrm{B} 3-\mathrm{C}-\mathrm{D} \\
\mathrm{A} 1 \neq \mathrm{D} 1, \mathrm{~A} 2 \neq \mathrm{C} 1-\mathrm{D} 1-\mathrm{D} 3\end{array}$ & \\
\hline
\end{tabular}

$\mathrm{N}=10$, for each combination of time, $\mathrm{pH}$ and elastic. Significant differences are indicated below each strain table for time intervals (A through $\mathrm{D}$ ) and the right for groups (SF and C) for the same time and $\mathrm{pH}$. *Statistically: Significant (S or $\neq$ ) or Nonsignificant (NS). 
between the groups tested ${ }^{21}$. These facts justify well designed in vitro studies. In the present study, factors such as the artificial saliva temperature and time in solution were kept as consistent as possible.

In this Investigation it was clear that the $\mathrm{pH}$ did not contribute significantly to force decay. Results showed a huge variation in initial force levels and force decay throughout time intervals, which is in agreement with other studies $^{7,9-10,12}$. The initial force (10 seconds) values ranged from $280 \mathrm{gf}$ to $490 \mathrm{gf}$. However, after 24 hours of strain, the force levels of all chain elastics ranged from $175 \mathrm{gf}$ to $190 \mathrm{gf}$. These differences are considered clinically important, because forces below 300 gf are clinically acceptable for the movement of a group of teeth or of a single tooth ${ }^{22-23}$. However, more importance than initial force levels was the subsequent force decay of the tested chains. Force decay due the variations between different products ${ }^{8-10}$ has been shown, and this was confirmed in the present experiment.

Irrespective of $\mathrm{pH}$, the largest force decay of $61 \%$ was reported for the super-force chain elastic, in comparison with $29 \%$ of the conventional type, at 24 hours. These differences were highly significant and of clinical interest. When force decay was examined over different time intervals, it was found that most changes were of little significance during the time intervals of 24 hours to 4 weeks, as is confirmed in the literature ${ }^{12,13}$.

With regard to the cytotoxicity test, the monolayer cell culture model together with the dye-uptake technique ${ }^{19}$ were used in the present study ${ }^{18,24}$, because the cytotoxicity of materials can be determined by spectrophotometry.

Spectrophotometric assay allows rapid and reliable evidence of cell viability to be obtained, based on the use of vital stain incorporated into viable cells. In this study, neutral red dye was used because it is widely used for identification of L929 cell viability ${ }^{18}$. Dead or damaged cells cannot incorporate vital stain, and are thus not recognized on optical reading. Therefore, spectrophotometry does not allow dead cells to be distinguished from the damaged ones ${ }^{18}$.

The choice of L929 mouse fibroblasts was due to the fact that they show results comparable with those of primary human gingival fibroblasts ${ }^{25,26}$, but one cannot interpret the cell culture results as a human response.

The development of non-latex chain elastics has become increasingly important for clinical use instead of latex elastics, because potentially cytotoxic intraoral elastics, such as latex ${ }^{27}$, may release substances that might be ingested by the patient over time, thus causing diseases resulting from a cumulative effect. However, stabilizing substances with cytotoxic character ${ }^{28}$ can be incorporated into the manufacturing process of non latex elastics ${ }^{28}$. In this context, this study had the intuit to verify if the elastics advertised as

\section{References}

1. Dos Santos RL, Pithon MM, Da Silva Mendes G, Romanos MT and De Oliveira Ruellas AC. Cytotoxicity of intermaxillary orthodontic elastics of different colors: an in vitro study. Journal being polyurethane are inert when tested on the cells. In the present study, the super-force chain elastics demonstrated similar cell viability to that of the conventional elastic.

The chain elastics evaluated in this study showed over $90 \%$ cell viability in all experimental periods, thus allowing one to affirm the high feasibility of using the evaluated materials. On the other hand, studies ${ }^{29}$ have reported that elastics showing cell viability of less than $50 \%$ should be avoided in order to prevent cumulative effects of the cytotoxic components released from these elastics into the body ${ }^{27}$.

This study showed that both elastics presented great cell viability and no influence of $\mathrm{pH}$ on the degradation of elastic strength, and no cytotoxicity were confirmed, suggesting an appropriate manufacturing process and/or the presence of non-cytotoxic stabilizing substances in the composition these non latex elastics.

Polyurethane chain elastics are thermoplastic polymers mainly processed by injection molding and by sintering. After the chemical reactions of polymerization that the originate, appear as amorphous masses, whose polymerics chains have relatively weak traction forces between them and chemical bonds randomly located along these chains $\mathrm{s}^{30}$. For that can improve their mechanical properties, the union between the side chains through cross covalently bonds are required using process, such as the vulcanization ${ }^{30}$.

Thus, three-dimensional structures are formed converting a flexible product in an resistant highly material, but elastic. In this study, the conventional chain elastic demonstrated to be more flexible than the super-force elastic, result of a different curing process, which is connected directly to degree of technology used, the refinement of the technique of production and the quality of raw materials used during manufacture ${ }^{30}$ of material.

In this context, the differences in force decay over time might be due to linear or cross-linked polymer composition in the chain, as well as to thermoplastic or thermoset materials and changes over time after elastic stretching. Thus, in order to clinically apply the most controlled force levels, appropriate products should be selected and initial forces measured to estimate the remaining force levels between 24 hours and subsequent chairside $\operatorname{control}^{7}$. Further studies are suggested to examine the lack of consistency in the degradation of super-force chain elastics.

\section{Conclusions}

The $\mathrm{pH}$ had no significant influence on the force decay and cytotoxicity. The time of use of chain elastics had a more deleterious influence and contributed to the variability in results, especially for super-force chain elastics of polyurethane. of Applied Oral Science. 2009; 17:326-9. PMid:19668992. http://dx.doi.org/10.1590/S1678-77572009000400010

2. Paige SZ, Tran AM, English JD and Powers JM. The effect of temperature on latex and non-latex orthodontic elastics. Texas Dental Journal. 2008; 125:244-9. PMid:18481612. 
3. Meyers MA and Chawla KK. Mechanical Behavior of Materials. Upper Saddle River: Prentice-Hall; 1999.

4. Wang T, Zhou G, Tan X and Dong Y. Evaluation of force degradation characteristics of orthodontic latex elastics in vitro and in vivo. Angle Orthodontist. 2007; 77:688-93. PMid:17605476. http://dx.doi.org/10.2319/022306-76

5. Tran AM, English JD, Paige SZ, Powers JM, Bussa HI and Lee RP. Force relaxation between latex and non-latex orthodontic elastics in simulated saliva solution. Texas Dental Journal. 2009; 126:981-5. PMid:19911618.

6. Sauget PS, Stewart KT and Katona TR. The effect of $\mathrm{pH}$ levels on nonlatex vs latex interarch elastics. Angle Orthodontist. 2011; 81:1070-4. PMid:21609184. http://dx.doi. org/10.2319/011811-34.1

7. Buchmann N, Senn C, Ball J and Brauchli L. Influence of initial strain on the force decay of currently available elastic chains over time. Angle Orthodontist. 2012; 82(3):529-35. PMid:22077188. http://dx.doi.org/10.2319/062011-399.1

8. Wong AK. Orthodontic elastic materials. Angle Orthodontist. 1976; 46:196-205. PMid:1064346.

9. Ash JL and Nikolai RJ. Relaxation of orthodontic elastomeric chains and modules in vitro and in vivo. Journal of Dental Research. 1978; 57:685-690. PMid:279583. http://dx.doi.org/ $10.1177 / 00220345780570050301$

10. Andreasen GF and Bishara S. Comparison of alastik chains with elastics involved with intra-arch molar to molar forces. Angle Orthodontist. 1970; 40:151-8. PMid:5269949.

11. Young $\mathrm{J}$ and Sandrik JL. The influence of preloading on stress relaxation of orthodontic elastic polymers. Angle Orthodontist. 1979; 49:104-9. PMid:286562.

12. Hershey HG and Reynolds WG. The plastic module as an orthodontic tooth-moving mechanism. American Journal of Orthodontics. 1975; 67:554-562. http://dx.doi. org/10.1016/0002-9416(75)90300-0

13. Baty DL, Storie DJ and Von Fraunhofer JA. Synthetic elastomeric chains: a literature review. American Journal of Orthodontics and Dentofacial Orthopedics. 1994; 105:536-542. http://dx.doi. org/10.1016/S0889-5406(94)70137-7

14. Ferriter JP, Meyers Junior CE and Lorton L. The effect of hydrogen ion concentration on the force-degradation rate of orthodontic polyurethane chain elastics. American Journal of Orthodontics and Dentofacial Orthopedics. 1990; 98:404-410. http://dx.doi.org/10.1016/S0889-5406(05)81648-8

15. Ramazanzadeh BA, Jahanbin A, Hasanzadeh $\mathrm{N}$ and Eslami N. Effect of sodium fluoride mouth rinse on elastic properties of elastomeric chains. Journal of Clinical Pediatric Dentistry. 2009; 34:189-92. PMid:20297715.

16. Fraunhofer JAV, Coffelt MTP and Orbell GM. The effects of artificial saliva and topical fluoride treatments on the degradation of the elastic properties of orthodontic chains. Angle Orthodontist. 1992; 62:265-274.

17. Huget EF, Patrick KS and Nunez, LJ. Observations on the elastic behavior of a synthetic orthodontic elastomer. Journal of Dental Research. 1990; 69:496-501. PMid:2307753. http:// dx.doi.org/10.1177/00220345900690021601

18. Dos Santos RL, Pithon MM, Martins FO, Romanos MT and De Oliveira Ruellas AC. Evaluation of the cytotoxicity of latex and non-latex orthodontic separating elastics. Orthodontics and Craniofacial Research. 2010; 13:28-33. PMid:20078792. http://dx.doi.org/10.1111/j.1601-6343.2009.01469.x

19. Neyndorff HC, Bartel DL, Tufaro F and Levy JG. Development of a model to demonstrate photosensitizer-mediated viral inactivation in blood. Transfusion. 1990; 30:485-490. PMid:2165643. http://dx.doi.org/10.1046/ j.1537-2995.1990.30690333476.x

20. Beattie $S$ and Monaghan P. An in vitro study simulating effects of daily diet and patient elastic band change compliance on orthodontic latex elastics. Angle Orthodontist. 2004; 74:234-9. PMid:15132450.

21. Sonis AL, Van der Plas E and Gianelly A. A comparison of elastomeric auxiliaries versus elastic thread on premolar extraction site closure: an in vivo study. American Journal of Orthodontics. 1986; 89:73-8. http://dx.doi. org/10.1016/0002-9416(86)90115-6

22. Quinn RS and Yoshikawa DK. A reassessment of force magnitude in orthodontics. American Journal of Orthodontics. 1985; 88:252-260. http://dx.doi.org/10.1016/ S0002-9416(85)90220-9

23. Lotzof LP, Fine HA and Cisneros GJ. Canine retraction: a comparison of two preadjusted bracket systems. American Journal of Orthodontics and Dentofacial Orthopedics. 1996; 110:191-6. http://dx.doi.org/10.1016/ S0889-5406(96)70108-7

24. Tomakidi P, Koke U, Kern R, Erdinger L, Kruger H, Kohl A et al. Assessment of acute cyto- and genotoxicity of corrosion eluates obtained from orthodontic materials using monolayer cultures of immortalized human gingival keratinocytes. Journal of Orofacial Orthopedics. 2000; 61:2-19. PMid:10682407. http://dx.doi.org/10.1007/BF02340928

25. Schedle A, Samorapoompichit P, Rausch-Fan XH, Franz A, Fureder W, Sperr WR et al. Response of L-929 fibroblasts, human gingival fibroblasts, and human tissue mast cells to various metal cations. Journal of Dental Research. 1995; 74:1513-1520. PMid:7560408. http://dx.doi. org/10.1177/00220345950740081301

26. Franz A, Konig F, Skolka A, Sperr W, Bauer P, Lucas T et al. Cytotoxicity of resin composites as a function of interface area. Dental Materials. 2007; 23:1438-1446. PMid:17688932. http:// dx.doi.org/10.1016/j.dental.2007.05.014

27. Schmalz G. Use of cell cultures for toxicity testing of dental materials-advantages and limitations. Journal of Dentistry. 1994; 22(Suppl 2):S6-11. http://dx.doi. org/10.1016/0300-5712(94)90032-9

28. Hwang CJ and Cha JY. Mechanical and biological comparison of latex and silicone rubber bands. American Journal of Orthodontics and Dentofacial Orthopedics. 2003; 124:379-386. http://dx.doi.org/10.1016/S0889-5406(03)00564-X

29. Hanson $M$ and Lobner D. In vitro neuronal cytotoxicity of latex and nonlatex orthodontic elastics. American Journal of Orthodontics and Dentofacial Orthopedics. 2004; 126:65-70. PMid:15224061. http://dx.doi.org/10.1016/j.ajodo.2003.07.006

30. Morton M. Rubber Technology. 3rd ed. Londres: Chapman \& Hall; 1995. 638 p. 